Удк 316.7

\title{
ЭТНИЧЕСКАЯ ИДЕНТИЧНОСТЬ МОЛОДЕЖИ ИЗ ЧИСЛА КОРЕННЫХ НАРОДОВ РОССИИ КАК УГРОЗА ЦЕЛОСТНОСТИ ГОСУДАРСТВА
}

\author{
Киселева Алина, \\ pluss@mail.com; yapluss@yandex.ru \\ МГУ им. М.В. Ломоносова, \\ Россия, 119991, г. Москва, Ленинские горы, 1
}

Киселева Алина, аспирант социологического факультета МГУ им. М.В. Ломоносова, сотрудник философского факультета МГУ.

\begin{abstract}
Актуальность исследования обусловлена мультикультурным и полиэтническим составом населения Российской Федерации, наличием национально-территориальных автономий. Существование автономных образований в стране с политической точки зрения представляет собой угрозу для ее существования. Как показывает история, страны с полиэтническим составом населения, в особенности, имеющие автономии, могут распадаться на отдельные независимые государства. Примером тому может служить распад СССР, Югославии, Чехословакии. В КНР, Испании, Великобритании происходят попытки автономных образований создать свои собственные национальные государства. Российская Федерация унаследовала от РСФСР свое административно-территориальное деление. В составе России 21 республика, в 12 из которых титульные этнические группы численно преобладают над русскими. В республиках имеются свои государственные языки, государственные символы и своя культурная политика. В то же время политика федерального центра последние 10 лет направлена на консолидацию российского общества, урезание полномочий региональных элит, присоединение автономных округов к населенным преимущественно этническими русскими областям и исключение национальных языков из числа обязательных предметов для изучения в школах, что с одной стороны укрепляет единство российской государственности, а с другой стороны ставит под угрозу культуры малочисленных народов страны. Еще одним минусом подобной политики является усиление сепаратистских настроений в республиках из-за языковой политики федерального центра. Все перечисленные обстоятельства делают данное исследование актуальным. Целью исследования является оценка угрозы целостности государства из-за влияния этнической идентичности коренных народов России на сепаратистские настроения среди молодежи. Методы. В процессе исследования был использован абстрактно-логический подход на основе системного анализа существующих эмпирических данных и онлайн-опроса, проведенного в Интернете с помощью сервиса «Google Формы» среди представителей молодежи коренных народов в возрасте от 18 до 35 лет. Результаты. Большинство опрошенных относят себя как к представителям своего народа, так и к общенациональной общности «россияне». 54,2 \% опрошенных согласны с утверждением, что наличие национальных республик в составе РФ несет угрозу распада страны в будущем, несогласны с этим утверждением 41,7 \% опрошенных. Более половины $(55,1 \%)$ опрошенных положительно относятся к идее экономической и политической самостоятельности своих регионов, две трети (65\%) опрошенных считают, что их регионы в будущем могут стать независимыми государствами.
\end{abstract}

Ключевые слова: Этнос, идентичность, молодежь, сепаратизм, регионализм, российская государственность, автономные республики. 
Россия - многонациональное государство с большим количеством национальных регионов. Национальные округа, республики и области были созданы в период развала Российской империи и образования СССР. Первые этнические автономии появились после февральской революции. Украина, Польша [1, С. 52-54], Финляндия [2] и Башкирия [3, С. 228] объявили себя либо независимыми государствами, либо автономиями в составе России. Пришедшие к власти большевики обещали народам России освобождение от великорусского шовинизма и построение равноправного союза народов. Однако, по мнению Владимира Путина, при образовании национальных автономий «была заложена мина под здание государственности» [4]. Несмотря на большую централизацию власти, в СССР проводилась политика коренизации, так как считалось, что руководящие должности в республиках должны занимать представители коренных народов, которые лучше знают специфику своего региона. Такой подход к управлению и административно-территориальному делению страны в действительности оказался губительным. Как только Центр ослабил рычаги управления, руководители автономий и союзных республик практически одномоментно стали провозглашать независимость своих территориальных образований. Развал СССР сопровождался не только разрушением экономических связей, но и этническими конфликтами. Они имели место почти во всех бывших союзных и автономных республиках. На сегодняшний день «неспокойная» ситуация по-прежнему сохраняется на Украине, Северном Кавказе, в Молдове, Таджикистане, Узбекистане и государствах Закавказья [5]. Межэтнические трения возникают и в Казахстане [6], где русскоязычное население севера и востока страны фактически дискриминируется. Что касается российских автономий, то ситуация в них также непростая. Например, в 1990-ые гг. по причине военных действий из Чечни бежали русские и представители других этносов, и теперь эта республика практически полностью моноэтнична. В республике Тыва почти 83 \% населения составляют тувинцы, а русских не более 16 \%. В Марий Эл, Якутии, Татарстане, Башкортостане, Карачаево-Черкессии, Калмыкии, Чувашии, Кабардино-Балкарии, Дагестане, Ингушетии абсолютное большинство составляют представители коренных народов [7]. В большинстве автономных округов и областей коренное население было в меньшинстве. Эти территории, как правило, населяли представители других народов России. Исключением были Агинский Бурятский и Коми-Пермяцкий автономные округа, где коренное население численно преобладало над другими народами, однако в процессе укрупнения регионов эти округа вошли в состав Читинской и Пермской областей с одновременным переименованием последних в края [8, С. 62-65; 9, С. 64].

В статье о национальных особенностях России, американский исследователь Дж. Хейс приводит слова историка Джеймса Биллингтона: «Россия похожа на Америку, хотя у нее совсем другая история, совсем другое развитие, но они схожи в том смысле, что это своего рода широкая цивилизация, а не просто страна. Это мультикультурная страна, она впитала в себя все виды различных культурных влияний и этнических групп, и все же у них, как и у нас, очень сильное чувство национальной идентичности» [10].

Однако стоит отметить, что если в США все граждане страны являются американцами, то есть представителями одной общенациональной идентичности, то в России общенациональная идентичность «россияне» не стала равнозначной американской национальной идентичности.

Джеффри Хейс добавляет к этому, что, в отличие от США, Россию сложно рассматривать как «плавильный котел» этнических групп: «Русские проводят четкое различие между этнической и национальной принадлежностью. Большинство русских 
считают, что нет таких понятий, как русский татарин, русский чеченец или афрорусский. Определение того, кто является и кто не является русским, также является сложным вопросом» [10].

Здесь стоит рассмотреть вопрос: что понимается под термином «национальная идентичность»? Согласно Генри Тэджфелу, национальная идентичность - это чувство принадлежности человека к государству или к нации [11, С. 10]. Юнми Ли рассматривает национальную идентичность как чувство «осознания различия», деления на «мы» и «они» [12, С. 29].

Будучи коллективным феноменом, национальная идентичность формируется как прямой результат взаимодействия и сплетения различных элементов общественной жизни - национальных символов, языка, истории нации, национального самосознания и культурных артефактов. Позитивное проявление национальной идентичности - это патриотизм, который характеризуется национальной гордостью и позитивными эмоциями любви к своей стране. Крайним проявлением национальной идентичности является шовинизм, который выражается в твердой вере в превосходство своей нации и абсолютной лояльности по отношению к своему народу.

В моноэтнических государствах, таких как Польша или Япония, должно было бы быть больше предпосылок к шовинистическим взглядам, чем в полиэтнических государствах, таких как Россия. Однако большинство развитых государств проводят политику мультикультурализма, но при этом наследие фашистских и националистических режимов первой половины XX в. влияет на межкультурные отношения в этих странах. Развитые страны стали центрами притяжения для мигрантов из самых разных стран. В странах Западной Европы сложилась парадоксальная ситуация: иммигранты остаются частью своих этнических сообществ, в то время как коренным жителям западноевропейских государств приходится приспосабливаться к серьезным социокультурным изменениям, связанным с нарастающим потоком иммигрантов из стран Ближнего Востока и Африки.

Россия является домом для множества разных народов, но все это этнокультурные разнообразие является частью большой российской гражданско-национальной идентичности. Следует отметить, что этническое самосознание некоторых народов России всегда было выше общероссийского. Однако, по мнению А.Л. Сафонова, в современном мире от четверти до половины населения планеты находятся в дуализме национальной и этнической идентичности. Причем, чтобы относить себя к представителям определенного этноса, необязательно знать его культуру, обычаи или язык [13, С. 241].

Не менее важным этнокультурным процессом в современной России является выделение субэтносов русского народа в отдельные этнические общности с новыми национальными идентичностями. К таким субэтносам относятся каменщики, поморы, семейские, камчадалы, казаки и другие. Но достаточно ли отличий у сибиряков, поморов или казаков для выделения их в отдельные этносы? А.Н. Худолеев отмечает, что в России намеренно создаются новые этнические идентичности, а отсутствие официального регулирования определения этнической принадлежности порождает различные спекуляции и националистические инсинуации: «несомненно, самым успешным информационным проектом по созданию новой национальной идентичности с перспективой самоопределения и отделения от России в составе государства является проект "Ингерманландия" и "ингерманландцы"» [14].

По мнению В.Н. Шевченко, процесс дезинтеграции России уже запущен, автор приводит лишь две позиции по этому вопросу: «Первая позиция состоит в утверждении о том, что в стране идут процессы дезинтеграции, ослабления единства и целостности 
государства и вполне возможен и вероятен их переход в активную фазу... Другая позиция, сложившаяся в литературе, отличается тем, что авторы не просто фиксируют сложность ситуации, по их мнению, она говорит о необходимости сохранения нынешней формы российского государства, хотя возможно эта форма и не является оптимальной. Но главное, авторы постоянно говорят, бьют тревогу, предупреждают, что власти давно пора действовать решительно, чтобы переломить ситуацию, ослабить, если не "заморозить" совсем действие нежелательных процессов и тенденций» [15, С. 8-9].

Однако Е.С. Яготинская считает, что «регионы государства стремятся к автономии только в том случае, если они имеют высокий уровень экономического развития, способны к "выживанию" отдельно от целостного государства. Более того, предполагается, что регион, который предпринимает попытки отделения, будет иметь более высокий уровень правового, политического, экономического, военного развития, чем тот, который существовал в материнском государстве» [16, С. 139]. Тем не менее, как известно, республики бывшего СССР провозглашали свой суверенитет без оглядки на возможный экономический ущерб для них. Как отмечает А.В. Бредихин сепаратистские попытки на Кубани среди казаков продолжаются и сегодня [17, С. 36-44].

За призывы к сепаратизму российское законодательство предусматривает наказание, при этом в 2014 г. к России, путем проведения референдума, присоединился Крым - регион другой страны. При этом, с точки зрения Украины, жители Крыма являются сепаратистами. Присоединение Крыма в нашей стране называют «правом на самоопределение», в то время как для большинства стран мира это «аннексия». Как отмечает ряд американских исследователей, включая А. Григас, К. Мур, нынешняя российская политика направлена на воссоздание империи [18, С. 4], где роль автономных регионов будет снижаться, а территория расширяться согласно «доктрине Караганова» [19, С. 3-20]. В.Л. Толстых отмечает, что «воссоединение Крыма и России, тем не менее, может быть обосновано принципом самоопределения. При его толковании должна учитываться идея общей воли, суть которой состоит в том, что люди должны иметь возможность участвовать в политике, а их интересы должны учитываться правительством. Правом на сецессию в такой трактовке обладают группы, исключенные из политического общения и не пользующиеся защитой правительства» [20, С. 499].

В настоящее время национальная идентичность в России - это дискуссионный вопрос. Так, миллиардер М.Д. Прохоров на съезде партии «Гражданская платформа» в 2012 г. предложил отказаться от деления России на национальные округа и республики, заявив следующее: «Я хочу поставить вопрос на обсуждение: а так ли эффективно разделение нашей страны на национальные округа и национальные республики? Мы сами своими руками создали национальное гетто, где местная коррумпированная власть угнетает и грабит наших людей, причем всех национальностей... Не лучше ли честно сказать, что данная сталинско-ленинская система уже больше не эффективна в условиях двадцать первого века... Не лучше ли нам честно и открыто обсудить этот вопрос и перейти к изменению территории с точки зрения экономической целесообразности. Да, для этого придется менять Конституцию...» [21].

Так или иначе, этническое самосознание народов России порождает волну националистических проявлений, в особенности среди молодежи. Молодежь всегда являлась двигателем прогрессивных идей, но в то же время она является одной из самых деструктивных социальных групп. С помощью молодежи в свое время пришел к власти Пол Пот, молодежь активно вовлекали в нацистскую организацию Гитлерюгенд, молодежь была основным действующим субъектом в событиях 1968 г. во Франции. На сегодняшний день молодежь национальных образовании России имеет ярко выраженную этни- 
ческую идентичность. Особенно это заметно на примере молодежи республик Северного Кавказа: стрельба в воздух из огнестрельного оружия стала отличительной особенностью поведения молодых чеченцев из богатых семей. В то же время этническая идентичность является важной характеристикой в сплочении народа. В 2017 г. разразился скандал вокруг юмористической программы на одном из федеральных каналов, где в качестве одного из персонажей выступала девушка по вызову - ингушка по национальности. Одного упоминания о существовании ингушских проституток на телевидении хватило, чтобы молодые люди из Северного Кавказа атаковали офис телекомпании и потребовали извинений. Руководство канала признало свою ошибку и в течение месяца в своем эфире актеры и телеведущие озвучивали извинения ингушскому народу [22].

На данный момент подобные инциденты не ограничиваются республиками Северного Кавказа. Зачастую межэтнические конфликты происходят по вине молодых людей. В связи с чем мы решили провести исследование, основной целью которого стало желание узнать насколько крепко национальное самосознание у молодых людей - представителей коренных и малых народов России, чувствуют ли они общность с остальным российским обществом и на сколько сильны сепаратистские настроения у представителей российских этносов. Так как возможности собрать в одном месте представителей наиболее крупных коренных этносов России не представлялось возможным, мы провели опрос в сети Интернет. В опросе принимали участие молодые люди в возрасте от 18 до 35 лет, представители республик и автономных округов Российской Федерации, включая представителей Башкортостана, Бурятии, Ингушетии, КабардиноБалкарии, Калмыкии, Карачаево-Черкесии, Коми, Марий Эл, Мордовии, Татарстана, Тывы, Удмуртии, Хакасии, Чувашии, Чеченской республики, Чукотского АО и Якутии (Саха). В исследовании принимали участие субэтносы русского народа (поморы, казаки), проживающие в Архангельской и Ростовской областях, а также представитель эвенского народа из Хабаровского края. Общее число респондентов в выборочной совокупности - 49 человек. Поиск участников проводился в сети Интернет на официальных сайтах национальных образований и культурных центров народов России, в социальных сетях, а также среди студентов МГУ имени М.В. Ломоносова и ВШЭ с помощью методов стратификационной выборки (выборка среди малых этносов России и русских субэтносов). Опрос проводился с помощью сервиса «Google Формы» в сети Интернет с 15 января по 15 марта 2019 г. [23]. Участникам исследования предлагалось ответить на небольшой блок вопросов. Результаты исследования представлены ниже.

Первые два вопроса касались места проживания (указаны выше) и этнической принадлежности респондентов (все опрошенные являются представителями титульных этносов указанных автономных территорий, этническим или субэтническим меньшинством неавтономных регионов). На вопрос о том, по каким критериям респонденты относят себя к той или иной этнической группе, участники опроса указали, что они относят себя к определенной этнической группе по следующим критериям: владение языком своей этнической группы $(42,86 \%)$, по рождению $(34,69 \%)$, по отличительным атрибутам культуры, внешнего облика и самобытности (10,2 \%), затруднились с ответом $12,24 \%$ опрошенных.

На вопрос «Считаете ли Вы, что у Вас присутствует национальная идентичность своего народа?» большинство респондентов ответили утвердительно, лишь 1 \% опрошенных ответили отрицательно. При этом у большинство опрошенных (79,6 \%) также присутствует и общенациональная идентичность - россияне. 


\section{По каким критериям Вы относите себя к определенному этносу? Why do you identify yourself as a member of a certain ethnic group? (49 ответов/49 answers)}

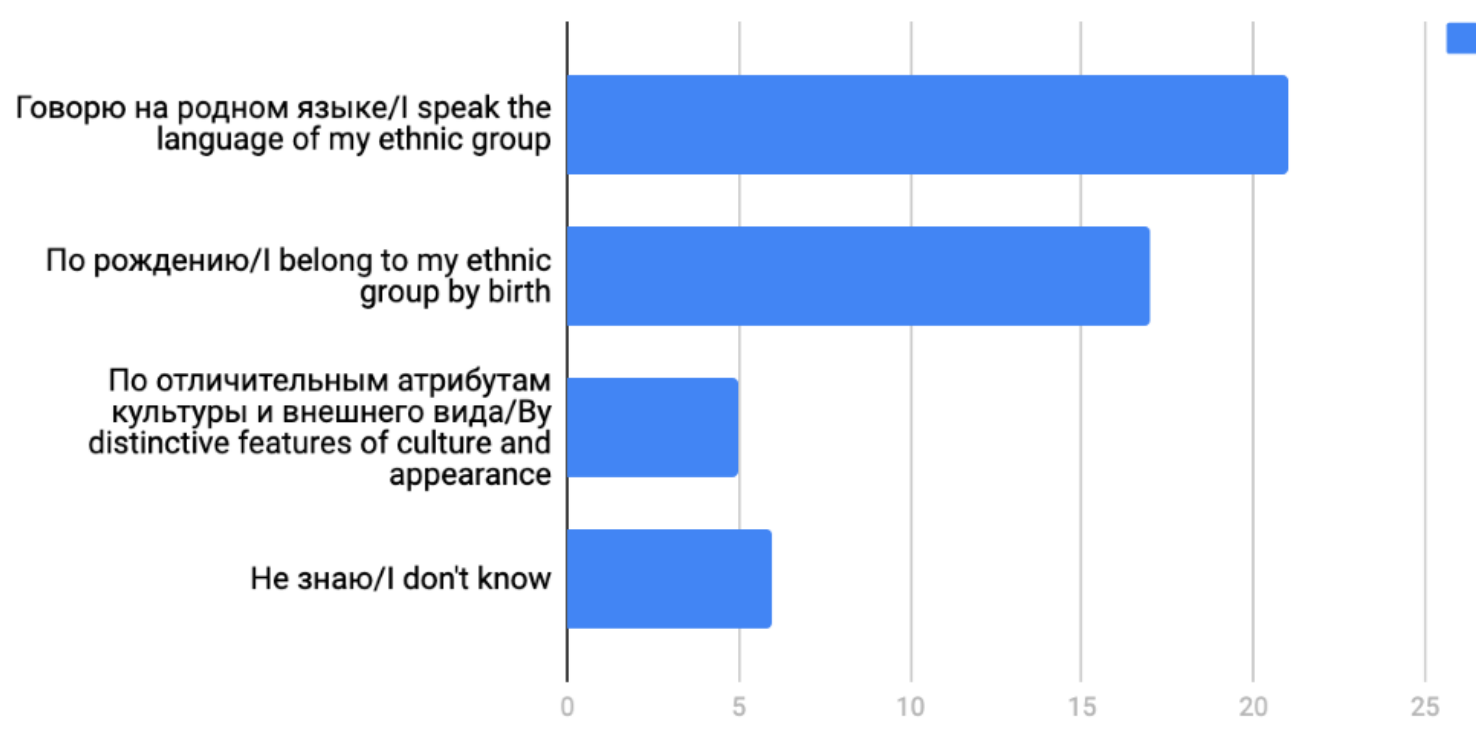

Puc. 1. Причины отнесения себя к определенному этносу

Fig. 1. Reasons for identifying as a member of an ethnic group

Относите ли Вы себя к национальной общности «россияне»?

49 ответов

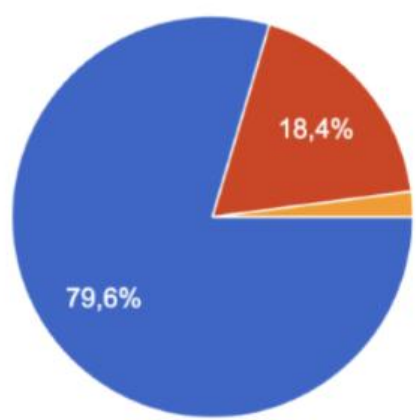

Да Yes

- Нет No

Не знаю I don't know

Do you identify yourself as member of the national group «Rossiyane» (citizen of Russia)

49 answers

Puс. 2. Общенациональная идентичность российских народов

Fig. 2. National identity of the Russian peoples

На вопрос «Что означает для Вас быть представителем Вашей национальности?» 20 \% опрошенных ответили, что горды быть представителями той или иной национальности. Столько же ответили на этот вопрос фразой «быть якутом», «быть чеченцем» и т. п. Прозвучали и такие ответы: «быть частью своего народа, учить язык, изучать культуру своего народа, ценить обычаи и традиции», «сохранять культуру, язык и обычаи моего народа», «иметь связь со своим народом, уважать своих предков, их борьбу за независимость», «помнить свои корни», «быть лицом и духом народа», «наличие культурного единства со своим народом», «быть сопричастным к истории и культуре 
своей страны». Один из респондентов пожаловался на искаженное произношение наименования его народа: «быть коми, а не комяком» [23].

Важной составляющей этнической идентичности является язык. В ходе опроса выяснилось, что национальным языком владеет лишь половина опрошенных $(53,2$ \%), остальные либо владеют им очень слабо, либо не знают его вовсе $(38,3 \%)$ [23].

На вопрос: «Верно ли суждение: наличие автономных республик в РФ является угрозой для распада страны в будущем?» более половины опрошенных согласились с тем, что наличие национально-территориальных автономий в России угрожает в будущем целостности страны.

\section{Верно ли суждение: наличие автономных образований в РФ является угрозой для распада страны в будущем? Do you think the existence of autonomous territory in Russia poses a threat to the territorial integrity of Russian Federation? (49 ответов/49 answers)}

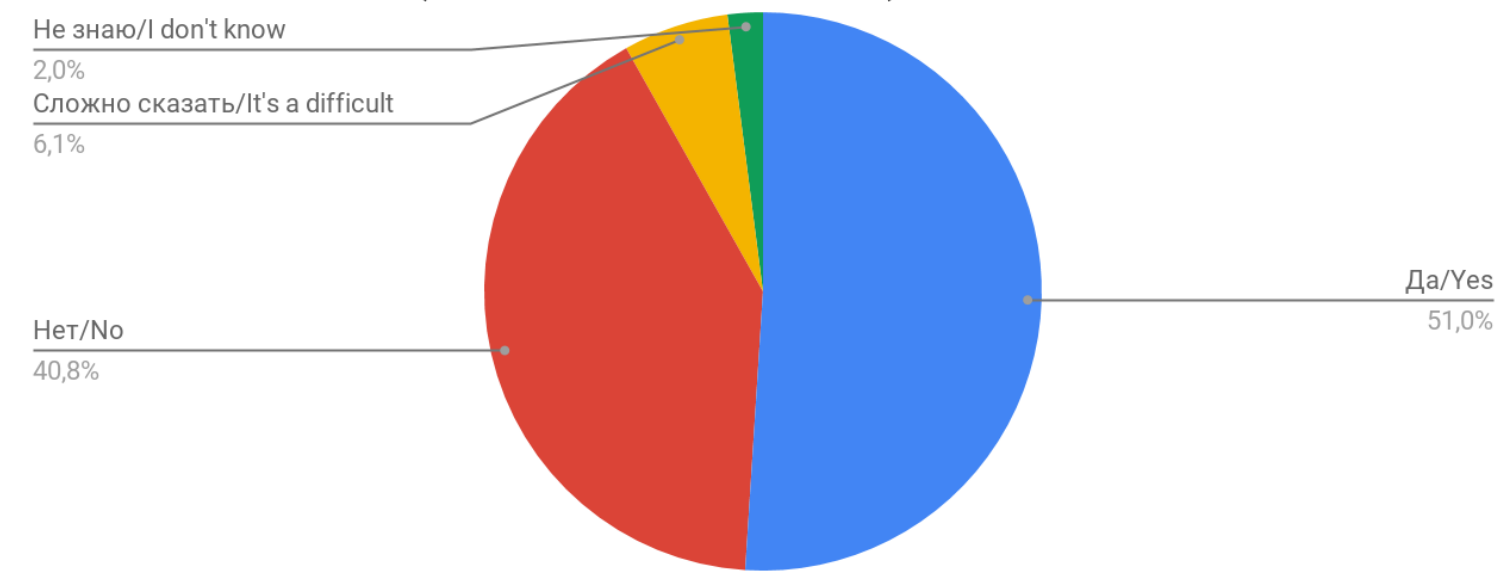

Рис. 3. Оценка угрозы распада страны участниками опроса

Fig. 3. Assessment of the threat of disintegration of the country by the survey participants

Более половины опрошенных (55,1 \%) положительно относятся к идее экономической и политической самостоятельности своих регионов. $8 \%$ опрошенных считают, что их национальные регионы достаточно независимы, 5,2 \% опрошенных сомневаются в том, что их автономии когда-либо в будущем станут экономически и политически независимыми: «было бы, наверное, неплохо, но у нас очень маленький народ и вряд ли он будет когда-нибудь самостоятельно решать государственные дела, хотя я не исключаю этого», «эвенки расселены по всей Сибири, поэтому это маловероятно».

На вопрос считают ли респонденты возможной и желательной независимость региона от России в будущем 53,1 \% ответили положительно, 34,7 \% отрицательно. $10,2 \%$ респондентов считают, что такая возможность существует, затруднились с ответом $2 \%$ опрошенных.

Комментируя свои ответы, респонденты отмечают, что положительно относятся к идее независимости их региона по причине текущего социально-экономического состояния в регионе: «Мы были независимой страной до 1940-ых годов. Сейчас наш регион бедный... Алкоголизм, бедность и нищета - это все реалии нашей республики. Федеральный центр вовсе не заботится о процветании региона, поэтому было бы лучше если бы мы были независимым государством». Некоторые респонденты считают закономерной будущую самостоятельность своих регионов: «Это закономерно: национальные государства сейчас являются основами большинства стран мира». 


\section{Как Вы относитесь к идее экономической и политической самостоятельности Вашей автономии/региона? 49 ответов}
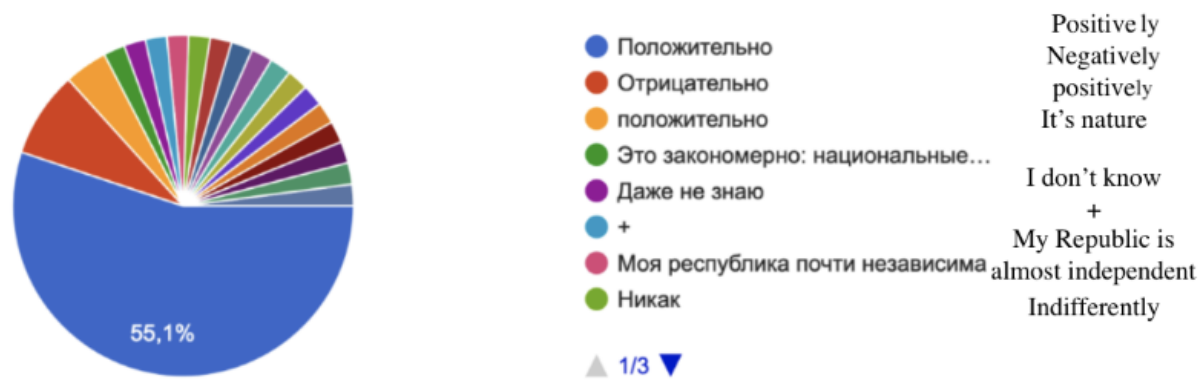

How do you feel about the idea of economic and political autonomy of your region?

49 answers

Puс. 4. Отношение респондентов к экономической

и политической самостоятельности регионов

Fig. 4. Respondents' attitude to economic and political independence of their regions

Считаете ли Вы возможной и желательной независимость Вашего региона от России в будущем?/ Do you think that independence of your region from Russian Federation is possible or even desirable? (49 ответов/49 answers)

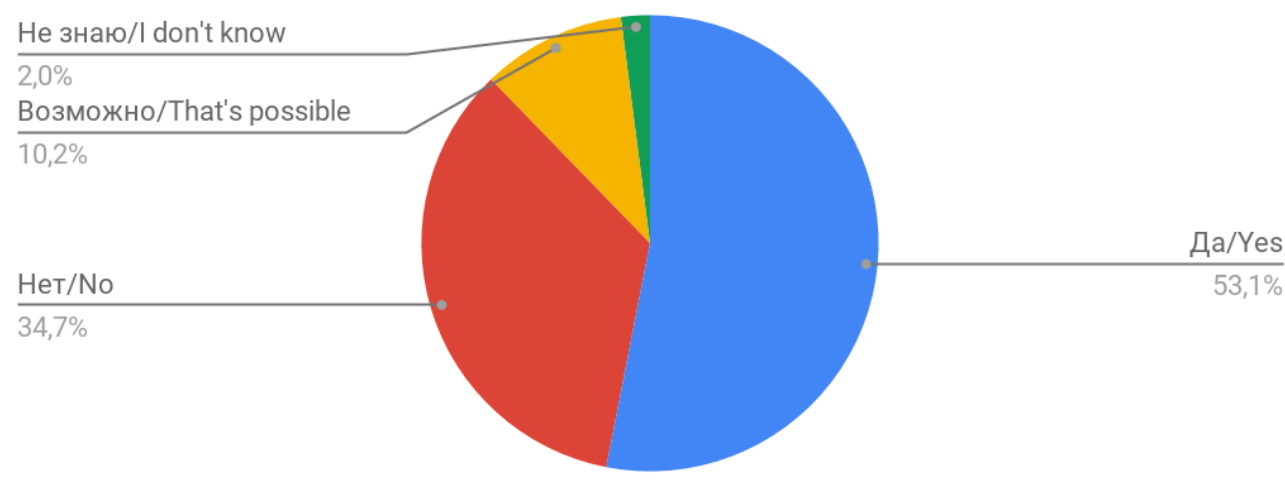

Puc. 5. Cепаратистские настроения среди респондентов

Fig. 5. Separatist sentiments among respondents

Таким образом, этническая идентичность хоть и оказывает значительное влияние на становление национального самосознания, она пока не играет ключевой роли в развитии сепаратистских настроений у молодежи из числа коренных национальных меньшинств в России. Опасность распространения сепаратизма среди представителей автономных образований страны возникает скорее по причине социально-экономической неудовлетворенности и отсутствия перспектив у молодых людей, что вместе с этническим самосознанием в будущем может привести к угрозе распада государства. 


\section{СПИСОК ЛИТЕРАТУРЫ}

1. Левицький К.А. Великий зрив: (до історії української державності від березня до листопада 1918 р. на підставі споминів та документів). - Львів: Видавнича кооператива «Червона калина», 1931. 149 c.

2. Народу Финляндии // Heninnen.net. URL: http://heninen.net/sopimus/1917i.htm (дата обращения 12.04.2019).

3. Еникеев 3.И. Правовой статус Башкортостана в составе России. - Уфа: Гилем, 2002. - 374 с.

4. Путин раскритиковал Ленина за идею равноправия республик с правом выхода из СCCP // Interfax.ru. URL: https://www.interfax.ru/russia/491443 (дата обращения 12.04.2019).

5. Помарета Э. 25 лет межэтнических конфликтов на постсоветском пространстве // ИноCMИ. URL: https://inosmi.ru/social/20161211/238374383.html (дата обращения 15.04.2019).

6. Александров Д. На всем постсоветском пространстве идут процессы консолидации националистических сил. URL: https:/www.pravda.ru/news/expert/1209063-alexandrov/ (дата обращения 15.04.2019).

7. Население по национальности и владению русским языком по субъектам российской федерации // Всероссийская перепись населения 2010. URL: http://www.gks.ru/free_doc/new_site/perepis2010/ croc/Documents/Vol4/pub-04-04.pdf (дата обращения 12.04.2019)

8. Анучина Н.П. Объединение Читинской области и АБАО: экспертное мнение // Вестник ЧитГУ. 2011. - № 12 (79). - С. 61-65.

9. Шабаев Ю.П. Этносоциальные последствия объединения регионов (из опыта формирования Пермского края) // Социологические исследования. - 2006. - № 3. - С. 64-71.

10. Hays J. Minorities and ethnic diversity in Russia. URL: http://factsanddetails.com/russia/ Minorities/sub9_3a/entry-5093.html (дата обращения 12.04.2019).

11. Tajfel H., Turner J. The social identity theory of intergroup behavior // Psychology of intergroup relations / Eds. S. Worchel, W. Austin. - Chicago: Burnham Inc Pub., 1986. - P. 7-24.

12. Lee Yoonmi. Modern Education, Textbooks, and the Image of the Nation: Politics and Modernization and Nationalism in Korean Education, 1880-1910. - New York: Garland Publishing, Inc., 2000. - 160 p.

13. Сафонов А.Л., Орлов А.Д. Этнос и глобализация: этнокультурные механизмы распада современных наций: монография. - СПб.: ЛИТЕО, 2017. - 335 с.

14. Худолеев А.Н. Формирование новых национальных идентичностей как угроза национальной безопасности // ОБЗОР.НЦПТИ. - 2017. - № 2 (11). - С. 8-13.

15. Шевченко В.Н. К дискуссиям вокруг темы «Распад России»: в поисках оптимальной формы российского государства // Философские науки. - 2015. - № 2. - с. 7-23.

16. Яготинская Е.С. Право народов на самоопределение: сепаратизм в России // Актуальные вопросы права, экономики и управления. Сборник статей VII Международной научно-практической конференции. - Пенза: Наука и Просвещение, 2017. - С. 137-140.

17. Бредихин А.В. Казачий сепаратизм на юге России // Казачество. Геополитика и патриотическое воспитание. - 2016. - № 14. - С. 36-45.

18. Grigas A. Beyond Crimea: The New Russian Empire - New Haven: Yele University Press, 2016. - 352 p.

19. Moor K.R. Will the Karaganov doctrine turn south? The potential for Russian intervention in northern Kazakhstan. The thesis for the Master of Social Science degree. - Denver, 2017. - 67 p.

20. Толстых Л.В. «Российская доктрина международного права после аннексии Крыма»: рецензия на книгу А.В. Задорожного // Евразийский юридический журнал. - 2019. - № 2 (129). - С. $499-504$.

21. Прохоров предложил отказаться от деления РФ на «национальные округа» // РИA Новости. URL: https://ria.ru/20121027/907211203.html (дата обращения 12.04.2019).

22. Comedy Club показал номер про ингушскую девушку из службы эскорта. Пришлось приносить извинения и вызывать ОМОН для защиты // Медуза. URL: https://meduza.io/feature/2017/12/11/comedyclub-pokazal-nomer-pro-ingushskuyu-devushku-iz-sluzhby-eskorta-prishlos-prinosit-izvineniya-i-vyzyvatomon-dlya-zaschity (дата обращения 15.04.2019).

23. Результаты опроса. URL: https://drive.google.com/file/d/0B5q4bbsnewDudFBveHVONE5raGEwL Wh4WkVRdW1SNGsyclZv/view?usp=sharing (дата обращения 12.04.2019).

Дата поступления: 15.04.2019. 
UDC 316.7

\title{
ETHNIC IDENTITY OF INDIGENOUS YOUTH IN RUSSIA AS A THREAT TO THE INTEGRITY OF THE STATE
}

\author{
Alina Kisseleva, \\ ppluss@mail.com; yapluss@yandex.ru \\ Lomonosov Moscow State University, \\ GSP-1, Leninskie Gory, Moscow, 119991, Russia.
}

\begin{abstract}
Alina Kisseleva, postgraduate student, employee, Lomonosov Moscow State University.
\end{abstract}
Relevance of the study is caused by the multicultural and polyethnic composition of the population of the Russian Federation and the presence of autonomous territories with their own official languages. The existence of autonomous territories within a nation-state poses a threat to its territorial integrity. Such nationstates often disintegrate, recent examples of this are USSR, Yugoslavia, Czechoslovakia. Autonomous regions in China, Spain, Great Britain attempt to become independent nation-states. Russian Federation inherited from RSFSR its administrative division. Russia has 21 autonomous republics, in 12 of them their titular ethnic groups outnumber ethnic Russians. Autonomous republics have their own official languages, state symbols and cultural policies. In the last 10 years however federal government's policies aim at consolidating Russian society, cutting regional elites' power, merging autonomous okrugs with ethnic Russian majority oblasts and abolishment of the mandatory titular languages classes in schools. This strengthens national unity, but on the other hand this threatens cultures of small indigenous peoples and can promote separatist sentiments in autonomous republics. All these circumstances make the study relevant. The aim of the study is to assess the threat to territorial integrity of Russian Federation due to the influence of the ethnic identity of the indigenous peoples of Russia on separatist sentiments among young people. Methods. The abstract-logical approach based on a systematic analysis of existing empirical data was used and an online survey was conducted using Google Forms service among representatives of indigenous youth aged 18-35. Results. The majority of respondents identify themselves as both members of their ethnic groups and members of the national group «Rossiyane» (citizens of Russia). 54,2\% of respondents agree that the presence of autonomous territories within the Russian Federation could possibly constitute a threat to the territorial integrity of the State, and $41,7 \%$ of respondents disagree with the above statement. More than half $(55,1 \%)$ of respondents have a positive attitude towards economic and political autonomy of their regions. Two thirds (65\%) of respondents think that their regions could in the future become independent states.

Key words: Ethnicity, identity, youth, separatism, regionalism, Russian statehood, autonomous republics.

\section{REFERENCES}

1. Levitskiy K.A. Velikij zriv: (do istoriï ukraïns'koï derzhavnosti vid bereznja do listopada 1918 r. na pidstavi spominiv ta dokumentiv) [Great failure: (to the history of Ukrainian statehood from March to November 1918 on the basis of memories and documents)]. Lvov, Vidavnicha kooperativa «Chervona kalian», 1931. $149 \mathrm{p}$.

2. Narodu Finlyandii [To the people of Finland]. Heninnen.net. Available at: http://heninen.net/sopimus/ 1917i.htm (accessed 12 April 2019).

3. Enikeev Z.I. Pravovoy status Bashkortostana v sostave Rossii [The legal status of the Republic of Bashkortostan in structure of Russia]. Ufa, Gilem Publ., 2002. 374 p. 
4. Putin raskritikoval Lenina za ideyu ravnopraviya respublik s pravom vykhoda iz SSSR [Putin criticized Lenin for the idea of equality of republics with the right to withdraw from the USSR]. Interfax.ru. Available at: https://www.interfax.ru/russia/491443 (accessed 12 April 2019).

5. Pomareta E. 25 let mezhetnicheskikh konfliktov na postsovetskom prostranstve [25 years of ethnic conflict in the post-Soviet space]. InoSMI. Available at: https://inosmi.ru/social/20161211/238374383.html (accessed 15 April 2019).

6. Aleksandrov D. Na vsem postsovetskom prostranstve idut protsessy konsolidatsii natsionalisticheskikh sil [In the former Soviet space are the processes of consolidation of nationalist forces]. Available at: https:/www.pravda.ru/news/expert/1209063-alexandrov/ (accessed 15 April 2019).

7. Naselenie po natsionalnosti i vladeniyu russkim yazykom po subektam rossiyskoy federatsii. Vserossiyskaja perepis naseleniya 2010 [Population by nationality and Russian language proficiency by subjects of the Russian Federation. All-Russian population census 2010]. Available at: http://www.gks.ru/free_doc/ new_site/perepis2010/croc/Documents/Vol4/pub-04-04.pdf (accessed 12 April 2019).

8. Anuchina N.P. Association of the Chita region and ABAO: expert opinion. Vestnik ChitGU, 2011, no. 12 (79), pp. 61-65. In Rus.

9. Shabaev Yu.P. Ethno-social implications of linking regions (the experience of formation of the Perm region). Sotsiologicheskie issledovaniya, 2006, no. 3, pp. 64-71. In Rus.

10. Hays J. Minorities and ethnic diversity in Russia. Available at: http://factsanddetails.com/russia/Minorities/ sub9_3a/entry-5093.html (accessed 12 April 2019).

11. Tajfel H., Turner J. The social identity theory of intergroup behavior. Psychology of intergroup relations. $2^{\text {nd }}$ ed. Eds. S. Worchel, W. Austin. Chicago, Burnham Inc Pub., 1986. pp. 7-24.

12. Lee Yoonmi. Modern Education, Textbooks, and the Image of the Nation: Politics and Modernization and Nationalism in Korean Education, 1880-1910. New York, Garland Publishing, Inc., 2000. 160 p.

13. Safonov A.L., Orlov A.D. Etnos i globalizatsiya: etnokulturnye mekhanizmy raspada sovremennykh natsiy: monografiya [Ethnicity and globalization: ethnic and cultural mechanisms of the decay of modern Nations: a monograph]. St-Petersburg: LITEO Publ., 2017. 335 p.

14. Hudoleev A.N. Formirovanie novykh natsionalnkykh identichnostey kak ugroza natsionalnoy bezopasnosti [Formation of new national identities as a threat to national security]. OBZOR.NCPTI, 2017, no. 2 (11), pp. $8-13$.

15. Shevchenko V.N. To the discussions around the topic «Disintegration of Russia»: in search of the optimal form of the Russian state. Filosofskie nauki, 2015, no. 2, pp. 7-23. In Rus.

16. Yagotinskaya E.S. Pravo narodov na samoopredelenie: separatizm v Rossii [The right of peoples to selfdetermination: separatism in Russia]. Aktualnye voprosy prava, ekonomiki i upravleniya. Sbornik statey VII Mezhdunarodnoy nauchno-prakticheskoy konferentsii [Current issues of law, economics and management. Collection of articles of the VII International scientific conference]. Penza, Nauka i Prosveshchenie Publ., 2017. pp. 137-140.

17. Bredikhin A.V. Kazachiy separatizm na yuge Rossii [Cossack separatism in the South of Russia]. Kazachestvo. Geopolitika i patrioticheskoe vospitanie, 2016, no. 14, pp. 36-45. In Rus.

18. Grigas A. Beyond Crimea: The New Russian Empire. New Haven, Yele University Press, 2016. 352 p.

19. Moor K.R. Will the Karaganov doctrine turn south? The potential for Russian intervention in northern Kazakhstan. The thesis for the Master of Social Science degree. Denver, 2017. 67 p.

20. Tolstyh L.V. «Russian doctrine of international law after the annexation of Crimea»: review of the book by A.V. Zadorozhny. Evraziyskiy yuridicheskiy zhurnal, 2019, no. 2 (129), pp. 499-504. In Rus.

21. Prokhorov predlozhil otkazatsya ot deleniya RF na «natsionalnye okruga» [Prokhorov proposed to abandon the division of the Russian Federation into «national districts»]. RIA Novosti. Available at: https://ria.ru/20121027/907211203.html (accessed 12 April 2019).

22. Comedy Club pokazal nomer pro ingushskuyu devushku iz sluzhby eskorta. Prishlos prinosit izvineniya $i$ vyzyvat OMON dlya zashity [Comedy Club showed a gig about an Ingush girl from an escort service. They had to apologize and call the riot police to protect themselves.]. Meduza. Available at: https://meduza.io/feature/2017/12/11/comedy-club-pokazal-nomer-pro-ingushskuyu-devushku-iz-sluzhbyeskorta-prishlos-prinosit-izvineniya-i-vyzyvat-omon-dlya-zaschity (accessed 15 April 2019).

23. Rezultaty oprosa [The results of the survey]. Available at: https://drive.google.com/file/d/0B5q4bbsnew DudFBveHVONE5raGEwLWh4WkVRdW1SNGsyclZv/view?usp=sharing (accessed 12 April 2019).

Received: 15 April 2019. 